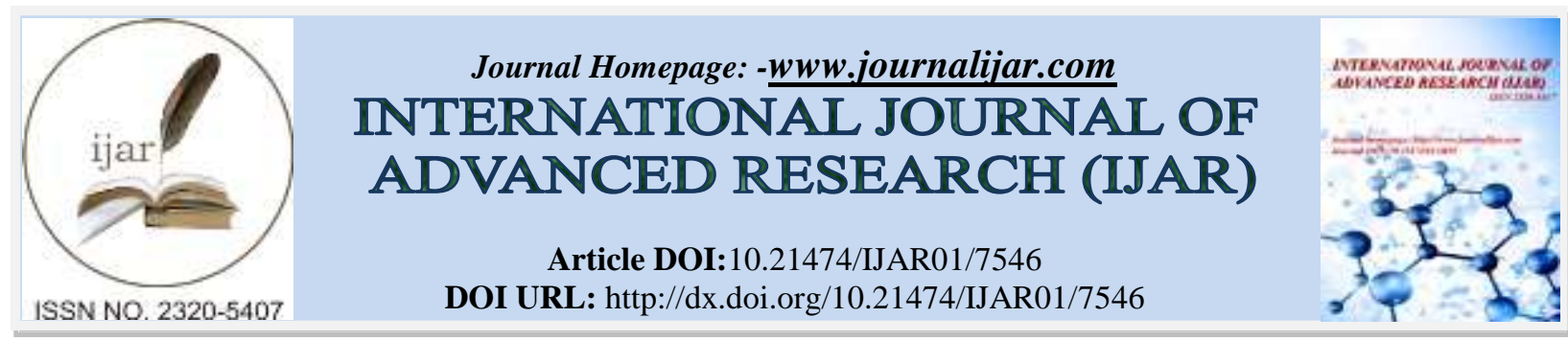

RESEARCH ARTICLE

\title{
THE RELATIONSHIP BETWEEN PERSONALITY TRAITS, AND SELF-EFFICACY ON THE LEVEL OF STUDENTS TEST ANXIETY.
}

\author{
Hena Fatma, MA and Prof. Akbar HusainRoma Seraj MA. \\ 1. Research Scholar: Professor and Dean Faculty of Social Science. \\ 2. Department of PsychologyAMU, Aligarh 202002.
}

\section{Manuscript Info}

\section{Manuscript History}

Received: 12 June 2018

Final Accepted: 14 July 2018

Published: August 2018

Keywords:-

Personality traits, anxiety, self-

efficacy, individual differences.

\section{Abstract}

This research aimed at studying the relationship between personality traits, and self-efficacy in the level of student with test anxiety. One hundred ten part-time students (male and female) from the second year and fourth semester completed the measure of test anxiety, self-efficacy and personality traits. Results revealed no significant relationship was found between personality traits and self-efficacy in the level of test anxiety among male and female and second and fourth-year students. A negative significant relationship was found between test anxiety and personality traits

Copy Right, IJAR, 2018,. All rights reserved.

\section{Introduction:-}

In the last decade, there has been a remarkable resource of interest in investigating moral rationality and personality, and efficacy. Although the concern with the moral self-service store was never absent from the cognitive developmental approach to moral reasoning. The behavioral feature from the earlier stage of maturity to justice the reasoning did not leave much room for cognitive development reflection on how moral it interacts with the psychological process. This research will certainly provide the may how students are performing the task and whether they are meeting their accomplish desired goals and intellectual standard. In general, the present research aimed to investigates: firstly, the association between student's anxiety and specific personality traits such as neuroticism and conscientiousness on the test, secondly, gender differences on test anxiety, thirdly, the relationship of self-efficacy, personality traits with anxiety test.

\section{Test anxiety:-}

Everyone feels anxious now and then. It is a normal emotion. For example, you may feel nervous when faced with a difficulty at school, and the workplace before taking an anxiety test, or before making an important decision. Anxiety is not the same as fear, which is a response to a real or perceived immediate threat, whereas anxiety is the expectation of future threat. Anxiety is a feeling of uneasiness and worry, usually generalized and unfocused as an overreaction to a situation that is only subjectively seen as menacing. It is often accompanied by muscular tension, restlessness, fatigue, and problems in concentration. Anxiety can be appropriate, but when experienced regularly the individual may suffer from an anxiety disorder. El-Zahhar and Hocevar (1991) found that the evidence for a particularly high level of anxiety test in Arab countries were extreme consequences to performance the attached to an examination of high school. Anxiety becomes maladaptive while it evokes, in susceptibility of an individual, selfpreoccupying thoughts that interfere with attention to the environments and to the task that must be dealt with. Finding of the earlier studies has a detrimental impact on the preference (Akgun \& Cierrochi, 2003, Struthere, Perry, 
$\&$ Menec, 2000). A research carried out by Cizer and Burg (2006), reported that the test anxiety affects up to $40 \%$ of students. More recently Bradly et al. (2010) found that $61 \%$ of students are affected by test anxiety at least some of the time and $26 \%$ almost always. Test anxiety has been conceptualized as the perception of assessment situations as threatening to the person's self-esteem and affecting the possibility of slightly judgment from others Spielberger (1972), reported that test anxiety as "a specific reaction to exam taking that can negatively influence a person's performance in relation to their capacity to prepare and to take a test of anxiety". While a small degree of anxiety can act as a motivator, tending to weaken something test anxiety can disrupt the mental process, especially when the task is demanding, such as the case of formal academic assessment (Daly \& Spalding, 2011). In the previous research it has shown that high test anxious people perform relatively poorly under an evaluative situation and that their performance is hindered by excessive self-preoccupations concerning their failure and its consequences (Sarason \& Stoop, 1978, Siepp, 1991, Covington \& Omelich, 1987).

Einat (2002) suggested that high test anxiety could be caused by high personal standards of an individual who except maximum success and are afraid that they cannot meet their own very high standards. The interpretation of the context of the testing situation is also more vital as to whether it will evoke anxiety. In the context of the task content, complexity, ambiguity, difficulty, novelty, interest, fairness, duration, time pressure, and whether it is evaluated as a threat, challenges or harmful.

\section{Personality traits and anxiety test:-}

Personality begins with traits. From birth onward, psychological individuality may be observed with respect to broad dimensions of behavioral and emotional style that cut across situations and contexts and readily distinguish one individual from another (Caspi, Roberts, \& Shiner, 2005).

The period of time personality has been extracted from the Latin Word "persona" which means that shadow mask. In the ancient Greece and Rome, the actors and warriors used to cover for all masking types to play has specific character. Thus, personality traits are used to in-terms of affecting others through in the aspect of external or internal appearance. In this research substantiation focused on that there are highlights of an individual differences between to evaluation of situation. In this, some people freeze when faced with an anxiety test as they are preoccupied with self-doubt and the consequences of fail in this test, whereas others are confident and approach the examination as an opportunity for receiving recognition. In general, personality traits and test anxiety, as personality factors play a vital role in the diversity of responses to stressor linked with academic goal striving.

The term personality is used to refer to those "psychological qualities that contributed to an individual's over a period of time and distinctive pattern of thoughts, feeling and behaving (Cervone and Pervish, 2008, p.8).

Personality theory has focused on the number of traits, or personality traits an individual can have. We can say that, personality traits defined as "consistent pattern in this way individuals behave, feel, and think" (Cervone, Pervin, 2008, p.238).

Eysenck and Eysenck (as cited by Cervone \& Pervin, 2008) identified two original orthogonal personality factors that were labeled "introversion-extroversion, and stability-neuroticism. An additional personality factors was later added labeled normality psychoticism (Eysenck \& Eysenck, 1985, Cervone \& Pervin, 2008).

(Mc-Crae and Costa, 1989), have suggested that there are five factor personality traits. This ideas has be operationalized within is known as "Big five factor personality trait inventory, Eysenckian approach by including the factors of "openness of experience" and "conscientiousness" are extraversion, neuroticism, openness of experience, and conscientiousness (Mc-Crae \& Costa, 1989, as cited by Cervone \& Pervin, 2008).

The personality domains of neuroticism and conscientiousness seem to be more significant to academic performance-related tasks, such as test-taking (Piedmout, 1995). Trapmann, Hell, Hirn, and Schuler`s (2007), meta analysis research investigator the impact of the five personality factors on academic prosperity at university. A total number of 258 coefficient correlation from 58 studies has been published since 1980. This research study showed that while neuroticism was related to academic satisfaction conscientiousness was associated with high academic achievement (Noftle \& Robins, 2007). The result was associated with 20 studies examining the relationship between conscientiousness and grade point average (GPD) students, conscientiousness was significantly positively linked to 
the academic outcome variable in 15 out of 20 studies within the mean effect size being 26 . Other studies reported that neuroticism had a positive correlation with test anxiety (Fitch, 2005, Tu \& Shi, 2008).

The present research study hypothesized that there would be a significant association between conscientiousness and test anxiety among participants. Further, the present investigators hypothesized there would be a significant positive correlation between neuroticism and test anxiety.

\section{Self-efficacy and test anxiety:-}

Self-efficacy has belief that one has the capabilities to carries out the races of actions required to manage different life situations. The concept of self-efficacy has been evolved from Bandura`s (1986) social cognitive theory. Goal the roots of self-efficacy, however, edge be traced to the beginnings of investigation one the self (Pajares \& Schunk, 2002). Bandura (1997) defined the term "self-efficacy" (Schwartz, Kwaitek, Schroder \& Zhang, 1997). The human functioning is commonly facilitated by a personal sense of control. If people credence that they can take action to solve a difficult situation, they become more willing to do something and so on. We can say that, they feel more committed to their own decision. The high self-efficacy and low self-efficacy can be either specific 20 a particular situation, such as academic performance tend to give up easily, dwell on their perceived deficiencies, thus a quality of their attention from the different task at hand: suffer from anxiety and stress, and attribution their achievement to external factors (Bandura, 1977, 1982, 1986). In academic achievement or evaluative situation, lower levels of selfefficacy are related both to higher anxiety test (Betz \& Hackett, 1983) and to greater reduction in task performance. Such a mediate path was supported in this research study by (Benson, Bandalos, \& Hutchenson, 1994). Although, the direct path was not, the general hypothesis of an effects of self-efficacy on performance, directly and indirectly via anxiety, however, was not supported by (Rouxel, 1999) when an individual differences in the level of knowledge were taken into account.

Many research investigators have shown that higher efficacies associated with lower anxiety level prior to preference difficult tasks in extension (Locke \& Latham, 1990, Martocchio, 1994, Wood \& Bandura, 1989). Hanna and Dempster (2009) reported that how anxiety influences students perceptions of their competence, but is perceive to have less affecting their actual scores. Arch reported that compared to male and female tend to devalue their academic performance and to have comparatively more positive thoughts during exam.

This current research study hypothesized that there would be significant negative correlation between the level of participants self-efficacy their anxiety test. The researcher also included self-efficacy as one of the predictors of the multiple regression analysis to determine its influences in the variance in the anxiety level of the sample.

\section{Methodology:-}

The sample one hundred students (60 males and 40 females) participants reviewed on this study. They were studying in the second semester and fourth semester of the regular psychology students of the women`s college and department of psychology, AMU, Aligarh. Out of 100 questionnaires, 63 were completed by second-semester students ( 24 males and 39 females), and 37 by fourth-semester students ( 21 males and 16 females).

\section{Tools:-}

1. The test anxiety scale (TAS) by Sarason (1980)

2. The Big five inventory (BFI), by John, Donahue, \& Kentle (1991)

3. The general self-efficacy scale by Schwarzer and Jerusalem (1995)

\section{Hypotheses:-}

H1: There will be a significant difference in self-reported test anxiety level between males and females.

H2: There will be a significant negative relationship between conscientiousness and self reported levels of test anxiety.

H3: There will be a significant positive relationship between neuroticism and self-reported levels of test anxiety.

H4: There will be a significant negative relationship between self-efficacy and self reported levels of test anxiety.

H5: Gender, personality traits, and self-efficacy will significantly predict the variance in test anxiety level. 


\section{Statistical analysis:-}

1. Means of frequencies percentage to describe participant characteristics.

2. Mean and standard deviation to identify degree to which respondents were responsive to instruments items.

3. Cronbach alpha determining internal consistency of instruments.

4. Descriptive statistics were to find the means and standard deviation of all the variables being tested.

Table 1:-Gender frequencies

\begin{tabular}{|l|c|c|c|c|c|}
\hline \multicolumn{7}{|c|}{ Descriptive Statistics } \\
\hline & $\mathrm{N}$ & Frequency & Percent & $\begin{array}{c}\text { Valid } \\
\text { Percent }\end{array}$ & $\begin{array}{c}\text { Cumulative } \\
\text { Percent }\end{array}$ \\
\hline AGE & 100 & 78 & 76.4 & 76.4 & 76.4 \\
\hline GENDER & 100 & 26 & 24.8 & 24.8 & 1.04 \\
\hline Valid N (listwise) & 100 & & & & \\
\hline
\end{tabular}

Table 2:-Descriptive statistics of psychological measure

\begin{tabular}{|c|c|c|c|c|}
\hline \multicolumn{5}{|c|}{ Descriptive Statistics } \\
\hline Variables & $\mathrm{N}$ & $\begin{array}{l}\text { Scores } \\
\text { range }\end{array}$ & Mean & Std. Deviation \\
\hline Test Anxiety & 100 & 0 to 37 & 16.13 & 6.57 \\
\hline Neuroticism & 100 & 1 to 5 & 2.87 & 0.84 \\
\hline Extroversion & 100 & 1 to 5 & 3.97 & .840 \\
\hline Openness of Ex. & 100 & 1 to 5 & 2.97 & .809 \\
\hline Agreeableness & 100 & 1 to 5 & 3.87 & .838 \\
\hline Conscientiousness & 100 & 1 to 5 & 3.75 & 0.78 \\
\hline Self-efficacy & 100 & 10 to 40 & 32.92 & 3.93 \\
\hline Valid N (listwise) & 100 & & & \\
\hline
\end{tabular}

Table 3:-Results of coefficient of correlation between the variables of the study

\begin{tabular}{|c|c|c|c|c|c|c|c|c|}
\hline \multicolumn{9}{|c|}{ Correlations } \\
\hline & & $\begin{array}{c}\text { Test } \\
\text { Anxi } \\
\text { ety }\end{array}$ & $\begin{array}{l}\text { Neurotic } \\
\text { ism }\end{array}$ & $\begin{array}{l}\text { Extrover } \\
\text { sion }\end{array}$ & $\begin{array}{c}\text { Openn } \\
\text { ess of } \\
\text { Ex. }\end{array}$ & $\begin{array}{c}\text { Agreeable } \\
\text { ness }\end{array}$ & $\begin{array}{c}\text { Agreeable } \\
\text { ness }\end{array}$ & $\begin{array}{c}\text { Self- } \\
\text { effica } \\
\text { cy }\end{array}$ \\
\hline \multirow[t]{3}{*}{ Test Anxiety } & $\begin{array}{l}\text { Pearson } \\
\text { Correlat } \\
\text { ion }\end{array}$ & 1 & $.324^{* * *}$ & $.208^{* * *}$ & $.285^{* *}$ & $.169^{* * *}$ & $.227^{* *}$ & $.361_{*}^{*}$ \\
\hline & $\begin{array}{l}\text { Sig. (2- } \\
\text { tailed) }\end{array}$ & & .000 & .000 & .000 & .000 & .000 & .000 \\
\hline & $\mathrm{N}$ & 100 & 100 & 100 & 100 & 100 & 100 & 100 \\
\hline \multirow[t]{3}{*}{ Neuroticism } & $\begin{array}{l}\text { Pearson } \\
\text { Correlat } \\
\text { ion }\end{array}$ & $.075_{*}^{*}$ & 1 & $.386^{* * *}$ & $.229^{* *}$ & $.182^{* * *}$ & $.469^{* * *}$ & $.297_{*}^{*}$ \\
\hline & $\begin{array}{l}\text { Sig. (2- } \\
\text { tailed) }\end{array}$ & .000 & & .000 & .000 & .002 & .000 & .000 \\
\hline & $\mathrm{N}$ & 100 & 100 & 100 & 100 & 100 & 100 & 100 \\
\hline \multirow[t]{3}{*}{ Extroversion } & $\begin{array}{l}\text { Pearson } \\
\text { Correlat } \\
\text { ion }\end{array}$ & $.324_{*}^{*}$ & $.276^{* *}$ & 1 & $.285^{* * *}$ & $.153^{* *}$ & .074 & $.369^{*}$ \\
\hline & $\begin{array}{l}\text { Sig. (2- } \\
\text { tailed) }\end{array}$ & .000 & .000 & & .000 & .003 & .204 & .000 \\
\hline & $\mathrm{N}$ & 100 & 100 & 100 & 100 & 100 & 100 & 100 \\
\hline \multirow[t]{2}{*}{$\begin{array}{l}\text { Openness of } \\
\text { Ex. }\end{array}$} & $\begin{array}{l}\text { Pearson } \\
\text { Correlat } \\
\text { ion }\end{array}$ & $.264_{*}^{*}$ & $.226^{* *}$ & $.410^{* *}$ & 1 & $.139^{* * *}$ & $.150^{* *}$ & $.333^{*}$ \\
\hline & Sig. (2- & .000 & .000 & .000 & & .010 & .003 & .000 \\
\hline
\end{tabular}




\begin{tabular}{|c|c|c|c|c|c|c|c|c|}
\hline & tailed) & & & & & & & \\
\hline & $\mathrm{N}$ & 100 & 100 & 100 & 100 & 100 & 100 & 100 \\
\hline \multirow[t]{3}{*}{$\begin{array}{l}\text { Agreeablenes } \\
\mathrm{s}\end{array}$} & $\begin{array}{l}\text { Pearson } \\
\text { Correlat } \\
\text { ion }\end{array}$ & $.476^{*}$ & $-.214^{* *}$ & $.663^{* *}$ & $.129^{* * *}$ & 1 & $-499^{* *}$ & $.227^{*}$ \\
\hline & $\begin{array}{l}\text { Sig. (2- } \\
\text { tailed) }\end{array}$ & .000 & .000 & .003 & .010 & & .000 & .008 \\
\hline & $\mathrm{N}$ & 100 & 100 & 100 & 100 & 100 & 100 & 100 \\
\hline \multirow[t]{3}{*}{$\begin{array}{l}\text { Conscientiou } \\
\text { sness }\end{array}$} & $\begin{array}{l}\text { Pearson } \\
\text { Correlat } \\
\text { ion }\end{array}$ & $.075^{-}$ & $.224^{*}$ & -.462 & $.311^{* * *}$ & $-640^{* * *}$ & 1 & $.125^{*}$ \\
\hline & $\begin{array}{l}\text { Sig. (2- } \\
\text { tailed) }\end{array}$ & .000 & .000 & .204 & .003 & .000 & & .000 \\
\hline & $\mathrm{N}$ & 100 & 100 & 100 & 100 & 100 & 100 & 100 \\
\hline \multirow[t]{3}{*}{ Self-efficacy } & $\begin{array}{l}\text { Pearson } \\
\text { Correlat } \\
\text { ion }\end{array}$ & -.262 & .283 & $-.427^{* *}$ & $.227^{*}$ & $.224^{*}$ & $.227^{* *}$ & 1 \\
\hline & $\begin{array}{l}\text { Sig. (2- } \\
\text { tailed) }\end{array}$ & .000 & .000 & .000 & .000 & .028 & .000 & \\
\hline & $\mathrm{N}$ & 100 & 100 & 100 & 100 & 100 & 100 & 100 \\
\hline
\end{tabular}

\section{Result and discussion:-}

This study shows there was a statistically significant difference between personality traits and self-efficacy in the level of test anxiety between male and females and between $2^{\text {nd }}$ and 4th-semester students. Further aim of the study was to explore the relationship between test anxiety and personality traits like neuroticism, extroversion, openness of experience, agreeableness, and conscientiousness. And further examine whether a relationship existed between test anxiety and self-efficacy. Moreover, the co-relational analyses used in the study shows no significant relationship between conscientiousness and test anxiety but a moderate positive significant relationship between neuroticism and test anxiety. A moderate significant relationship was found between test anxiety and self-efficacy. Female scored slightly higher than men's in their level of test anxiety, which is in line with the common suggestion of a higher level of test anxiety among females compared to males. Regarding these finding the relationship between individual's personality trait test anxiety, neuroticism scores have a much stronger relationship to test anxiety than conscientiousness. In this result we found that some researcher has been studying there is no significant relationship between test anxiety and conscientiousness but a moderate positive relationship between test anxiety level and neuroticism (Fitch, 2005, Tu, \& Shi, 2008).

In short, by looking at the different elements of the test anxiety (worry, tension, test irrelevant thoughts, and bodily symptoms) a more accurate relationship between test anxiety and conscientiousness could be found. These findings are in line with the main research study the strengthening of self-efficacy in test anxiety and internal consistency value ranges from .74 to .89 , (as five domains internal consistency was $\mathrm{N}=.79, \mathrm{E}=.79, \mathrm{O}=.80, \mathrm{~A}=.75, \mathrm{C}=.83$ ) found.

\section{Implications:-}

There are major important parameters linked to the psychological assessment of any individual; namely, personality traits, self-efficacy, and test anxiety. These ultimately determine the functionality of an individual, how the individual reacts and interacts with other members of the society. This study shall focus on the caregivers of children with autism spectrum disorder and try to determine the formative factors. 


\section{References:-}

1. Akgum, S., \& Ciarrochi, J. (2003). Learned resourcefulness moderates the relationship between academic stress and academic performance. Educational Psychology, 23(3), 287-294.

2. Bandura, A. (1986). Social Foundations of thoughts and action: A Social Cognitive Theory Englewood Cliffs. NJ: Prentice Hall.

3. Bandura. A. (1977). Self-efficacy: Toward a unifying theory of behavioral change. Psychological Review 84, 191-215.

4. Benson, J., Bandalos, D. L., \& Hutchison, S. (1994). Modeling Test Anxiety Among Male And Female Anxiety, Stress and Coping, 7, 131-148.

5. Betz, N. E., \& Hckett, G., C. (1983). The relationship of self-efficacy expectancies to the selection of sciencebased college majors. Journal of Vocational Behavior, 23,329-345.

6. Bradley, R., McCraty, R., Atkinson, M., Tomasino, D., Daugherty, A., \& Arguelles, L. (2010). Emotion selfregulation, psycho-physiological coherence and test anxiety: Results from an experiment using electrophysiological measures. Applied Psychophysiology and Biofeedback, 35(4), 261-283.

7. Caspi, A. Roberts, B. W., \& Shiner, R.L. (2005). Personality development: Stability and change. Annual Review of Psychology 56, 453-484.

8. Cervone, D. \& Pervin, L. A. (2000). Personality, Theory, and Research (10 ${ }^{\text {th }}$ Ed.), New York, NY: Wiley.

9. Cizek, G. J., \& Burg, S. S. (2006). Addressing Anxiety in a High Stress Environment: Strategies Classrooms and Schools. Thomas Oaks, CA, US: Corwin Press.

10. Convigton, M. V., \& Omelich, C. L. (1987). I knew it cold before the exam: A test of the anxiety blockage hypothesis. Journal of Educational Psychology, 79(4), 393-400.

11. Daly, A. L., Chamberlin, S., \& Spalding, V. V. (2011). Test anxiety, heart-rate and performance in anxiety level French speaking mock exam: An exploratory study. Educational Research, 53(3), 321-330.

12. Einat, A. (2000). Learning Disabilities-The Challenges (in Herbew). Tel Aviv, Israel: Reches Publishers, Educational projects.

13. El-Zahhar, N. E., \& Hocever, D. C. (1991). Cultural and sexual differences in test anxiety, traits anxiety, and personality. Journal of Cross Cultural Psychology, 22(2), 238-249.

14. Eysenck, H. J. (1985). The Biological Basis of Personality. Springfiled.

15. Fitch, B. D. (2005). A test of the relationship between personality traits and test anxiety (California). Dissertation Abstracts International Section A: Humanities and Social Science, 65(12-A). 4539.

16. Hanna, D., \& Dempster, M. (2009). The effect of statistics anxiety on students predicted and actual test scores. The Irish Journal of Psychology, 30(1-4), 201-209.

17. Locke, E. A., \& Latham, G. P. (1990). A Theory of Goal Setting and Task Performance. Englewood Cliffs, NJ: Prentice Hall.

18. Martocchio, J., J. (1994). Effects of conceptions of ability on anxiety, self-efficacy, and learning in training. Journal of Applied Psychology, 79, 819-825.

19. McCrae, R. R, \& Costa, P. T, Jr. (1989). Reinterpreting the Myers-Briggs type indicator from the perspective of the five-factor model of personality. Journal of Personality, 57, 17-40.

20. Noftle, E. E., \& Robins, R. W. (2007). Personality predictor of academic outcomes: Big five correlations of GPD \& SAT scores. Journal of Personality and Social Psychology, 93, 116-130.

21. Pajaras, F. (2002). Overview of social cognitive theory and self-efficacy. Social Cognitive Theory, 66, 543-578.

22. Piedmont, R. L. (1995). Another look of fear of success, fear of failure, and test anxiety: A motivational analysis using the five-factor model. Sex Roles, (3-4), 139-158.

23. Rouxel, G. (1999). Path analysis of the relations between self-efficacy, anxiety and academic performance. European of Psychology of Education, 14(3), 403-421.

24. Sarason, I. G., \& Stoops, R. (1987). Test anxiety and the passage of time. Journal of Consulting and Clinical Psychology, 46(1), 102-109.

25. Schmidt, L.A., \& Riniolo, T. C. (1999). The role of neuroticism in test and social anxiety. The Journal of Social Psychology, 139 (3), 394-395.

26. schwarzer, R., Bable, J., Kawaitek, P., Scroder, K., \& Zhang, J. X. (1997). The assessment of optimistic selfbeliefs: Compassion of the German, Spanish, and Chinese versions of the general self-efficacy scale. Psychology: Applied Psychology International Review, 46, 69-88.

27. Siepp, B. (1991). Anxiety and academic performance: A meta-analysis of findings. Anxiety Research, 4(1), 2741.

28. Spielberger, C.D. (1972). Anxiety as an emotional state. Anxiety: Current trends in theory and research (1), 3546. 
29. Struthers, C. W., Perry, R. P., Menec, W. H. (2000). An examination of the relationship among academic stress, coping, motivation and performance in college. Research in Higher Education, 41(5), 581-592.

30. Trapmann, S., Hell, B., Hirn, J. W., \& Schieler, H. (2007). Meta-analysis of the elationship between the big five and academic success at university. Zietschrift fur Psychologt/ Journal of Psychology, 215(2), 132-151.

\section{Ethical consideration:-}

1. Funding for any source: none

2. Conflict of interest: none of declare

3. Ethical principles have been observed as is primarily done in subjective empirical studies.

4. Acknowledgement: assistance rendered by my teachers and colleagues are acknowledged. 